УДК 81-2

ББК 81

DOI: https://doi.org/10.17308/lic.2021.4/3822

\title{
ВИЗУАЛИЗАЦИЯ МАРКЕМНЫХ СВЯЗЕЙ РУССКИХ ПОЭТОВ ПЕРВОЙ ТРЕТИ ХІХ ВЕКА
}

\author{
А. В. Кашкина
}

\section{VISUALIZATION OF MARKEME LINKS BETWEEN RUSSIAN POETS OF THE FIRST THIRD OF THE XIX ${ }^{\mathrm{TH}}$ CENTURY}

\begin{abstract}
A. V. Kashkina
Аннотация: цель настоящей статьи - пересмотр, обновление и дополнение результатов маркемного исследования русской поэзии, подразумевающее детальное описание взаимоотношений между авторами, их типичности/специифичности, а также наиболее распространенных маркем. Для достижения этой иели используются такие понятия, как индекс маркемной близости и индекс общесрезовой адекватности автора. Работа построена на материале списков маркем, выделенных из текстов 15 русских поэтов первой трети ХІХ в. При помощи стратификачии выявлены ядерная и периферийная маркемная лексика в общесрезовом маркемном списке и в списке связующих маркем, а также их доминанта и вище-доминанта. Тот же принцип, примененный к индивидуальнылм спискам маркем авторов в их сопоставлении с общесрезовым маркемном списком, позволяет определить типичных и специфичных представителей изучаемого хронологического среза. Взаимоотношения между авторами описываются при помощи индекса маркемной близости, зависящего от их общих маркем и отражающего степень их сходства, $и$ наглядно отображаются с помощью графов, отображающих цุентры аттракции авторов и направленные связи между ними.
\end{abstract}

Ключевые слова: маркема, индекс текстуальной маркированности, индекс маркемной близости, индекс общесрезовой адекватности, центт аттракции, общесрезовые маркемы, связующие маркемы.

\begin{abstract}
Russian poetry, implying a detailed description of interactions between authors, their typicality/uniqueness, as well as the most common markemes.To achieve this goal, the concepsts of Index of Markeme Similarity and Index of Relative Chronological Validity are used. The research is based on the lists of markemes extracted from texts by 15 Russian poets of the first third of XIX century. Via stratification, the core and the periphery of interval and linking markemes as well as their dominant and vice dominant are defined. The same approach applied to individual authors' lists of markemes, as compared to interval markeme list, allows establishing typical and unique representatives of the studied chronological interval. The relations of authors are described via the Index of Markeme Similarity depending on their common markemes and reflecting their similarity and visualized via graphs showing centers of attraction and directed links between them.
\end{abstract}

Key words: markeme, Index of Textual Markedness, Index of Markeme Similarity, Index of Relative Chronological Validity, centre of attraction, interval markemes, linking markemes.

\section{Введение}

Первая треть ХІХ в. в истории русской литературы, и в особенности поэзии, - период, представляющий интерес для исследования не только у литерату- роведов, но и у ученых-лингвистов, так как именно в это время складывается основной лексический состав современного русского языка. Возникновение и развитие романтизма, начало формирования реа-

(C) Кашкина А. В., 2021

Контент доступен под лицензией Creative Commons Attribution 4.0 License.

The content is available under Creative Commons Attribution 4.0 License. 
лизма, закат сентиментализма - все это находит свое отражение и в лексике, в том числе и в частотных характеристиках слов.

В данной работе, посвященной первой трети XIX в., мы продолжаем дополнение и уточнение итогов изучения русской поэзии средствами маркемного анализа, изложенных в [1]. Задачи настоящего исследования: 1) составление сводного списка маркем русских поэтов первой трети XIX в., выделение в нем ядерной и периферийной лексики, а также доминанты; 2) определение авторов-нуклеаров, употреблявших наиболее характерные для изучаемого хронологического среза маркемы, и авторов-маргиналов, маркемы которых для первой трети XIX в. нетипичны; 3) выявление направленных связей между поэтами на основе сходства их маркемных списков. Применяемые в работе термины - интегральный вес маркемы, индекс общесрезовой адекватности автора и индекс маркемной близости авторов - будут раскрыты в ходе изложения. Прочие понятия, используемые в маркемном анализе, подробно охарактеризованы, например, в [2].

\section{Материалы и методы}

Материалом исследования послужили тексты 15 поэтов первой трети XIX в. - Е. А. Баратынского, К. Н. Батюшкова, П. А. Вяземского, Н. И. Гнедича, А. А. Дельвига, В. А. Жуковского, И. И. Козлова, А. В. Кольцова, В. К. Кюхельбекера, М. Ю. Лермонтова, М. В. Милонова, А. Ф. Мерзлякова, А. С. Пушкина, К. Ф. Рылеева, Н. М. Языкова. Условные обозначения авторов, применяемые для компактности в ряде таблиц, приведены в табл. 1.

Т а б ли ц а 1

Условные обозначения поэтов первой трети ХІХв.

\begin{tabular}{|l|l|l|l|}
\hline \multicolumn{1}{|c|}{ Автор } & $\begin{array}{c}\text { Обозна- } \\
\text { чение }\end{array}$ & \multicolumn{1}{|c|}{ Автор } & \multicolumn{1}{|c|}{$\begin{array}{c}\text { Обозна- } \\
\text { чение }\end{array}$} \\
\hline Е. А. Баратынский & БАР & В. К. Кюхельбекер & КЮХ \\
\hline К. Н. Батюшков & БАТ & М. Ю. Лермонтов & ЛЕР \\
\hline П. А. Вяземский & ВЯЗ & А. Ф. Мерзляков & МЕР \\
\hline Н. И. Гнедич & ГНЕ & М. В. Милонов & МИЛ \\
\hline А. А. Дельвиг & ДЕЛ & А. С. Пушкин & ПУШ \\
\hline В. А. Жуковский & ЖУК & К. Ф. Рылеев & РЫЛ \\
\hline И. И. Козлов & КОЗ & Н. М. Языков & ЯЗЫ \\
\hline А. В. Кольцов & КОЛ & & \\
\hline
\end{tabular}

Сводный список маркем русской поэзии первой трети XIX в. сформирован на базе выделенных ранее авторских маркемных списков и включает 50 маркем, имеющих наибольший нормированный интегральный вес (НормИнВес). НормИнВес является количественным показателем значимости маркемы в поэтической лексике исследуемого периода и численно равен произведению суммы нормированных индексов текстовой маркированности (СумНормИнТеМ) на количество употребивших маркему авторов:

\section{НормИнВес $=$ СумНормИнтем $\times$ Кол-во авт.}

Стратификация маркемной лексики первой трети XIX в. производится на основе среднего значения НормИнВеса.

\section{Результаты исследования}

Среднее значение НормИнВеса маркем первой трети XIX в. - 1,4349. Таким образом, к ядерной маркемной лексике относятся первые 16 маркем сводного маркемного списка (в табл. 2 выделены полужирным шрифтом), а к периферийной - все остальные маркемы. Для получения более структурированных данных в этих двух множествах также выделяются ядро и периферия. Для ядерной маркемной лексики средний НормИнВес равен 2,764, в ядро входят 5 маркем (воспоминание, блаженство, счастье, наслаждение, благословение; выделены полужирным курсивом), а в периферию - 11 маркем (сердие, отечество, человек, вдохновение, страдание, радость, природа, добродетель, мгновенье, воображение, волнение); все эти маркемы используются не менее чем 7 авторами. Соответственно, для периферийной маркемной лексики средний НормИнВес составляет 0,809, к ядру относятся 15 маркем (сnокойствие, стремление, бессмертие, надежда, провидение, разговор, уединение, солние, сладость, молчанье, сновидение, призрак, пламень, богатство; выделены курсивом), а к периферии - 19 маркем (веселье, пространство, небосклон, преступление, приговор, взгляд, любовь, прелесть, благодарность, почелуй, мечтанье, заблуждение, очарование, восторг, чувство, успокоение, свобода, старость, несчастье). Доминантой маркемной лексики первой трети XIX в. является обладающая максимальным НормИнВесом маркема воспоминание, вице-доминантой - блаженство. Интересно, что в данном хронологическом срезе нет маркем, отмеченных у всех авторов; наиболее распространена (встречается у 14 поэтов) маркема счастье.

Маркемы, входящие в состав сводного маркемного списка поэзии первой трети XIX в., можно рассмотреть с точки зрения семантики, опираясь на принципы классификации, изложенные в работах О. Г. Артемовой [3], А. А. Кретова [4] и А. А. Фаустова [5]. Так, морально-этические маркемы в рассматриваемом хронологическом срезе немногосчисленны (добродетель, преступление, приговор), так же как и качественные (сладость, прелесть, молодость, cmaрость), и представлены в основном периферийной лексикой. Социальные маркемы (человек, богатство, отечество, благословение, свобода) и маркемы, 
Сводный список маркем первой трети ХIX в.

\begin{tabular}{|c|c|c|c|c|c|c|c|}
\hline Маркема & СумИнТеМ & Кол-во авт. & Интегр вес & Маркема & СумИнТеМ & Кол-во авт. & Интегр вес \\
\hline воспоминанье & 0,568822 & 11 & 6,257 & молчанье & 0,13734 & 8 & 1,099 \\
\hline блажеенство & 0,361036 & 12 & 4,332 & сновиденье & 0,159205 & 6 & 0,955 \\
\hline сuacmbe & 0,268319 & 14 & 3,756 & призрак & 0,116898 & 8 & 0,935 \\
\hline наслаждение & 0,388866 & 9 & 3,5 & пламень & 0,102501 & 9 & 0,923 \\
\hline благословенье & 0,426327 & 8 & 3,411 & богатство & 0,121028 & 7 & 0,847 \\
\hline сердце & 0,206572 & 13 & 2,685 & младость & 0,205037 & 4 & 0,82 \\
\hline отечество & $\mathbf{0 , 2 5 0 9 9 7}$ & 10 & 2,51 & веселье & 0,129863 & 6 & 0,779 \\
\hline человек & 0,198664 & 12 & 2,384 & пространство & 0,187611 & 4 & 0,75 \\
\hline вдохновение & $\mathbf{0 , 3 1 1 1 9 2}$ & 7 & 2,178 & небосклон & 0,119504 & 6 & 0,717 \\
\hline страданье & 0,237654 & 9 & 2,139 & преступление & 0,143189 & 5 & 0,716 \\
\hline радость & 0,170862 & 12 & 2,05 & приговор & 0,10195 & 7 & 0,714 \\
\hline природа & $\mathbf{0 , 1 5 9 3 8 1}$ & 12 & 1,913 & взгляд & 0,075207 & 8 & 0,603 \\
\hline добродетель & 0,237504 & 8 & 1,9 & любовь & 0,074296 & 8 & 0,594 \\
\hline мгновенье & 0,234181 & 8 & 1,873 & прелесть & 0,096882 & 6 & 0,581 \\
\hline воображенье & 0,263573 & 7 & 1,845 & благодарность & 0,143121 & 4 & 0,572 \\
\hline волненье & 0,16549 & 9 & 1,489 & поцелуй & 0,09533 & 6 & 0,572 \\
\hline спокойствие & 0,238703 & 6 & 1,432 & мечтанье & 0,09255 & 5 & 0,463 \\
\hline стремление & 0,174297 & 8 & 1,394 & заблужденье & 0,112631 & 4 & 0,452 \\
\hline бессмертье & 0,197067 & 7 & 1,379 & очарованье & 0,148223 & 3 & 0,445 \\
\hline надежда & 0,137578 & 10 & 1,376 & восторг & 0,073412 & 6 & 0,44 \\
\hline провиденье & 0,188151 & 7 & 1,317 & чувство & 0,085947 & 5 & 0,43 \\
\hline разговор & 0,155498 & 8 & 1,244 & успокоение & 0,035519 & 11 & 0,391 \\
\hline уединенье & 0,176135 & 7 & 1,233 & свобода & 0,077677 & 5 & 0,388 \\
\hline солнцее & 0,122822 & 9 & 1,105 & старость & 0,076878 & 5 & 0,384 \\
\hline сладость & 0,122082 & 9 & 1,099 & несчастье & 0,0745 & 5 & 0,373 \\
\hline
\end{tabular}

описывающие межличностные отношения (любовь, поцелуй, благодарность, уединение, молчание), играют более важную роль в сводном маркемном списке. Значительна и доля маркем, обозначающих фундаментальные понятия (пространство, мгновение, стремление, провидение, надежда, бессмертие), тогда как натурфакты, т. е. маркемы, связанные с окружающим миром, представлены лишь 4 маркемами, из которых только одна относится к ядерной лексике (природа, солнце, небосклон, пламень). Наиболее обширная семантическая группа маркем, как и для поэзии XVIII в. - эмоциональные маркемы (восторг, счастье, радость, блаженство, волнение, веселье, страданье, сердие, спокойствие, несчастье). Второй крупный класс маркем - ментально-перцептивные (взгляд, мечтанье, воображение, воспоминание, вдохновение, сновидение, заблуждение). Вероятно, такое соотношение семантических классов маркем обусловлено упадком классицизма с характерной для него философско-нравственной тематикой, а также возникновением и развитием в начале
XIX в. нового литературного направления - романтизма, в сферу интересов которого входит духовный мир личности не только в чувственном, но и в рациональном аспекте.

Сопоставляя полученный срезовый список маркем русской поэзии первой трети XIX в. с индивидуальными авторскими маркемными списками, можно определить наиболее характерных представителей этого периода. Для этого применяется такой параметр, как индекс общесрезовой адекватности автора (ИОСАд), представляющий собой сумму нормированных весов маркем данного автора, входящих в общий маркемный список. После вычисления ИОСАд для каждого из поэтов первой трети XIX в. определяется среднее для данного хронологического среза значение этой величины $(0,583205)$. Затем определяется разность индивидуального и среднего ИОСАд (обозначаемая как ABS в табл. 3). В свою очередь, среднее значение модуля ABS (в таблице представлено в столбце, озаглавленном «Разность») и служит базой для стратификации поэтов первой трети XIX в. 
с точки зрения типичности их маркемной лексики для указанного периода. Поэты с положительным значением параметра ABS, превышающим среднюю для данного временного промежутка величину $(0,08)$, причисляются к классу нуклеаров, т. е. наиболее характерных для данного среза авторов (в нашем случае это Е. А. Баратынский, А. А. Дельвиг и И. И. Козлов). Авторы с отрицательной величиной $\mathrm{ABS}$, превосходящей по модулю среднее значение, напротив, имеют наименее типичную для исследуемого периода маркемную лексику и включаются в класс маргиналов (В. И. Жуковский, П. А. Вяземский, Н. И. Гнедич). Все остальные рассматриваемые нами представители русской поэзии первой трети XIX в. образуют обширный класс авторов, не являющихся ни сверхтипичными, ни уникальными с точки зрения употребляемых ими маркем - медиаров (К. Н. Батюшков, А. В. Кольцов, В. К. Кюхельбекер, М. Ю. Лермонтов, М. В. Милонов, А. Ф. Мерзляков, А. С. Пушкин, К. Ф. Рылеев, Н. М. Языков). Поскольку в изучаемом нами хронологическом срезе максимальное по абсолютной величине значение ABS отрицательно, можно говорить о наличии в данном периоде супермаргинала Н. И. Гнедича, в маркемном списке которого встречаются лишь 9 из 50 общесрезовых маркем. Рисунок 1 наглядно демонстрирует распределение поэтов первой трети XIX в. по их типичности-специфичности для данного среза.
Т а б ли ц а 3

Индекс общесрезовой адекватности русских поэтов XVIII в.

\begin{tabular}{|c|c|c|c|}
\hline Автор & ИОСАд & AВS & Разность \\
\hline БАР & 0,750462 & 0,167257 & 0,167257 \\
\hline БАТ & 0,5999 & 0,016695 & 0,016695 \\
\hline ВЯЗ & 0,405922 & $-0,17728$ & 0,177283 \\
\hline ГНЕ & 0,379126 & $-0,20408$ & 0,204079 \\
\hline ДЕЛ & 0,694102 & 0,110897 & 0,110897 \\
\hline ЖУК & 0,464278 & $-0,11893$ & 0,118927 \\
\hline КОЗ & 0,748566 & 0,165361 & 0,165361 \\
\hline КОЛ & 0,573604 & $-0,0096$ & 0,009601 \\
\hline КЮХ & 0,591755 & 0,00855 & 0,00855 \\
\hline ЛЕР & 0,662749 & 0,079544 & 0,079544 \\
\hline МЕР & 0,54228 & $-0,04092$ & 0,040925 \\
\hline МИЛ & 0,601092 & 0,017887 & 0,017887 \\
\hline ПУШ & 0,617193 & 0,033988 & 0,033988 \\
\hline РЫЛ & 0,574325 & $-0,00888$ & 0,00888 \\
\hline ЯЗЫ & 0,54272 & $-0,04049$ & 0,040485 \\
\hline Средн. & 0,583205 & & 0,080024 \\
\hline
\end{tabular}

Сопоставляя друг с другом маркемные списки поэтов первой трети XIX в., можно получить представление об их взаимосвязи в пределах изучаемого хронологического среза и степени сходства их маркемной лексики. Для этого применяется так называ-

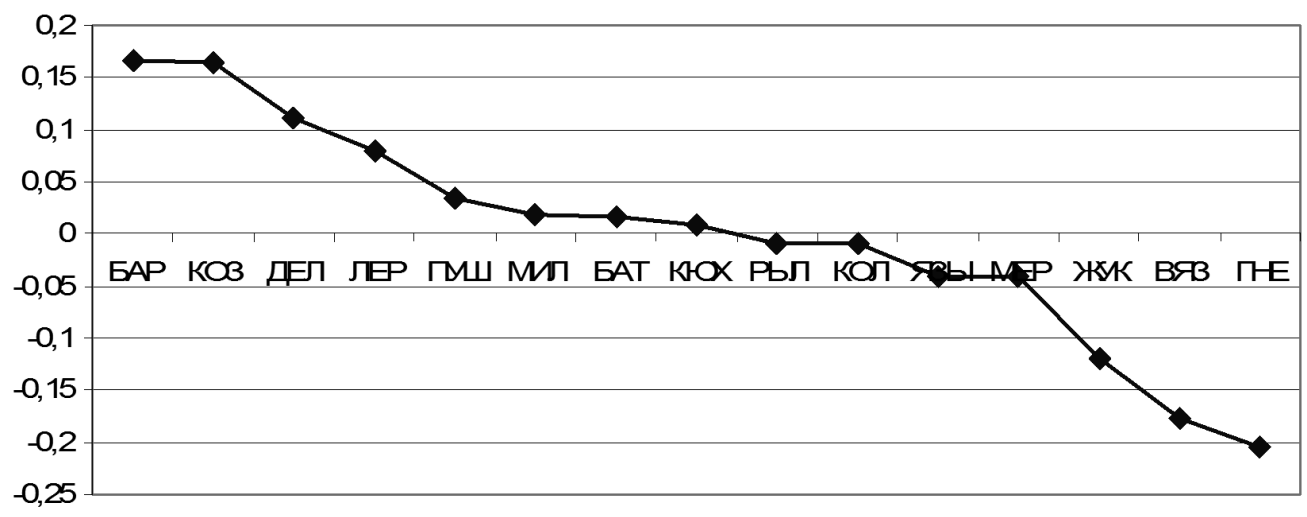

Puc. 1. Распределение поэтов первой трети XIX в. по типичности

емый индекс маркемной близости авторов (ИМаБ), который для данной пары авторов вычисляется как произведение сумм всех нормированных индексов текстовой маркированности совпадающих в их маркемных списках маркем:

$$
\begin{gathered}
\text { ИМаБ }_{\text {Авт } 1 \text { Авт 2 }}=\text { СумНормИнТеМ } \\
\quad \times \text { СумНорм } 1 \\
\times
\end{gathered}
$$

где СумНормИнТеМ ${ }_{\text {Авт1 }}$ и СумНормИнТеМ ${ }_{\text {Авт2 }}$ суммарный нормированный ИнТеМ общих маркем первого и второго автора пары. В табл. 4 содержатся данные об индексах маркемной близости для всех пар русских поэтов первой трети XIX в.

Максимальная для данного автора величина ИМаБ его маркемного списка с маркемной лексикой другого автора указывает на наличие предпочтительной маркемной связи между указанной парой авторов. Если этот параметр имеет наибольшее значение лишь для одного из авторов пары, то такая маркемная связь будет однонаправленной, в противном случае - взаимонаправленной, или обоюдной. Величина ИМаБ показывает силу межавторской связи. Маркемы, 


\begin{tabular}{|c|c|c|c|c|c|c|c|c|c|c|c|c|c|c|c|}
\hline 离 & 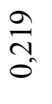 & $\stackrel{\Sigma}{E}$ & $\begin{array}{l}\text { के } \\
\text { mे } \\
0\end{array}$ & $\frac{\hat{0}}{0}$ & $\begin{array}{l}\text { o } \\
0 \\
0 \\
0\end{array}$ & 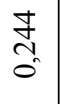 & $\begin{array}{l}\stackrel{ \pm}{\Xi} \\
0\end{array}$ & $\frac{\text { 卞 }}{0}$ & $\begin{array}{l}\hat{\mathbf{a}} \\
\text { הิ }\end{array}$ & $\begin{array}{l}\dddot{n} \\
\stackrel{0}{0}\end{array}$ & $\begin{array}{l}\stackrel{\infty}{n} \\
0\end{array}$ & $\begin{array}{l}\stackrel{D}{I}^{\circ} \\
\stackrel{0}{0}\end{array}$ & $\begin{array}{l}\text { ô } \\
0\end{array}$ & $\frac{\partial}{0}$ & - \\
\hline 客 & $\begin{array}{l}\mathbb{I} \\
0 \\
0\end{array}$ & $\begin{array}{l}\text { to } \\
\text { o. }\end{array}$ & $\begin{array}{l}\vec{\infty} \\
\overrightarrow{0}\end{array}$ & $\begin{array}{l}\text { 壳 } \\
0 \\
0\end{array}$ & $\begin{array}{l}\approx \\
\dddot{0} \\
0\end{array}$ & \begin{tabular}{l}
$\infty$ \\
$\stackrel{\infty}{\circ}$ \\
\hdashline
\end{tabular} & $\begin{array}{l}\text { : } \\
\text { ?. }\end{array}$ & $\begin{array}{l}\text { J } \\
0\end{array}$ & $\frac{\text { f }}{0}$ & $\begin{array}{l}\stackrel{8}{0} \\
\stackrel{0}{0}\end{array}$ & $\frac{\tilde{n}}{0}$ & $\begin{array}{l}\infty \\
0 \\
0\end{array}$ & $\begin{array}{l}\text { है } \\
\text { o. } \\
0\end{array}$ & - & $\begin{array}{l}\frac{\partial}{0} \\
\stackrel{0}{0}\end{array}$ \\
\hline$\stackrel{M}{\stackrel{\omega}{\oplus}}$ & $\begin{array}{l}\stackrel{0}{=} \\
0\end{array}$ & $\begin{array}{l}\infty \\
\text { oे } \\
0 \\
0\end{array}$ & $\begin{array}{l}\infty \\
\stackrel{0}{\circ} \\
0\end{array}$ & $\begin{array}{l}\text { : } \\
\vdots \\
0\end{array}$ & $\begin{array}{l}\text { ? } \\
0 \\
0 \\
0\end{array}$ & हे & $\begin{array}{l}\text { ta } \\
\text { oे }\end{array}$ & $\begin{array}{l}\hat{n} \\
0 \\
0\end{array}$ & $\frac{\grave{\Xi}}{0}$ & ¿̂े & $\begin{array}{l}\frac{7}{0} \\
\text { O. } \\
0\end{array}$ & ڤે & - & $\begin{array}{l}\text { \&ू } \\
0 \\
0\end{array}$ & $\hat{\delta}$ \\
\hline 罣 & $\begin{array}{l}\overrightarrow{\mathrm{\delta}} \\
0\end{array}$ & 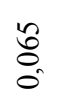 & $\bar{\sigma}$ & $\stackrel{\infty}{\circ} \stackrel{0}{\circ}$ & $\begin{array}{l}\vec{J} \\
0^{\circ}\end{array}$ & $\begin{array}{l}\text { हे } \\
\text { ठ. }\end{array}$ & $\begin{array}{l}\text { हे } \\
\text { : }\end{array}$ & $\begin{array}{l}\text { oे } \\
0 \\
0\end{array}$ & $\begin{array}{l}\tilde{N} \\
0 \\
0\end{array}$ & $\begin{array}{l}\text { I } \\
\text { O } \\
0\end{array}$ & $\tilde{\delta}$ & - & $\hat{\tilde{o}}$ & \begin{tabular}{l}
$\infty$ \\
\multirow{0}{0}{} \\
0
\end{tabular} & 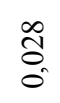 \\
\hline 点 & 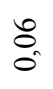 & $\begin{array}{l}\cong \\
\Rightarrow \\
0\end{array}$ & $\begin{array}{l}\text { ते } \\
\text { - }\end{array}$ & $\frac{\frac{7}{0}}{0^{\circ}}$ & $\mathscr{\delta}_{0}^{0}$ & $\stackrel{\overrightarrow{0}}{0}$ & $\begin{array}{l}\text { के } \\
\text { o. }\end{array}$ & $\frac{\text { I }}{0}$ & $\frac{8}{0}$ & $\begin{array}{l}\text { t } \\
\text { Oे } \\
0\end{array}$ & - & ô. & $\underset{8}{\mathbb{Z}}$ & $\frac{\pi}{n}$ & $\stackrel{\infty}{\stackrel{\infty}{0}}$ \\
\hline
\end{tabular}

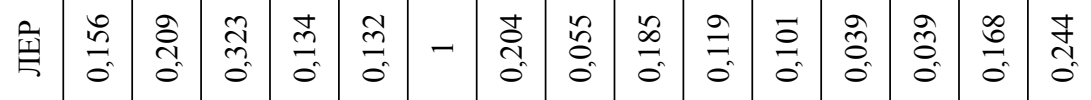

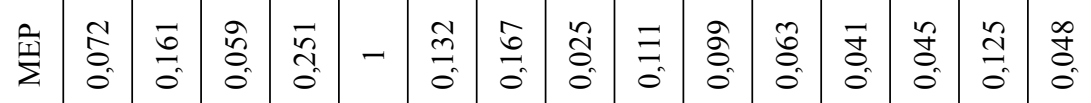

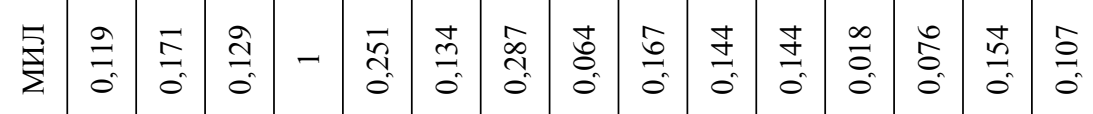

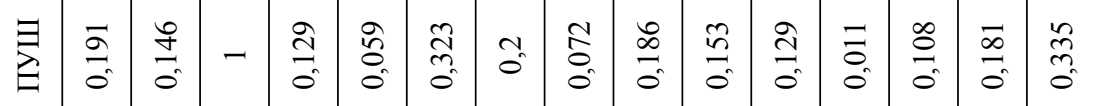

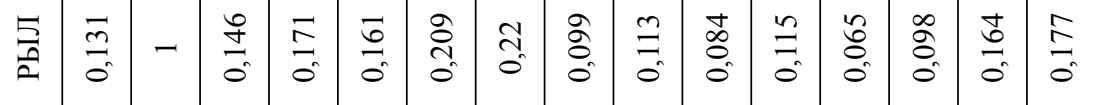

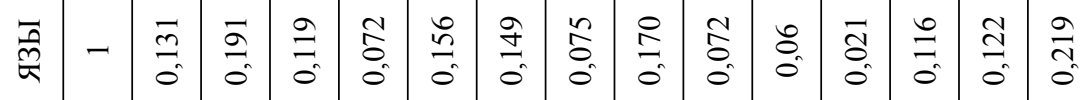

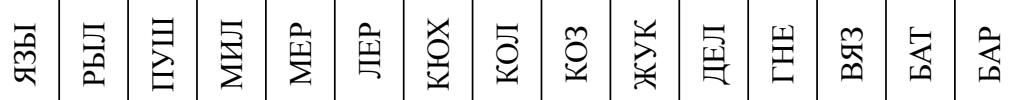


принимающие участие в формировании предпочтительных маркемных связей, называются связующими. Для рассматриваемого периода в их число попадают 77 маркем, приведенных в табл. 5. Сумма НормИнТеМ маркемы по всем поэтам, в предпочтительных маркемных связях которых она участвует, называется ее интегральным связующим весом (ИнСВес). Получившийся таким образом маркемный список, как и сводный список маркем первой трети XIX в., допускает стратификацию на основе среднего значения ИнСВеса $(0,10334)$, разделяющего его на ядро (содержит 28 маркем, выделено полужирным шрифтом в табл. 5) и периферию (включает 49 маркем соответственно).

Среди ядерных связующих маркем (на основе среднего ИнСВеса, равного 0,2045) можно, в свою очередь, выделить ядро (11 маркем: воспоминание, блаженство, наслаждение, вдохновение, благословение, счастье, воображение, страданье, мгновение, сердие, молодость, полужирный курсив) и периферию (17 маркем). Доминанта и вице-доминанта списка связующих маркем совпадают с таковыми для сводного маркемного списка первой трети XIX в. В более объемном классе периферийной связующей маркемной лексики со средним ИнСВесом 0,0455 на ядро приходится 21 маркема (в табл. 5 выделены курсивом), а на периферию оставшиеся 28 маркем.

Наиболее наглядно графически представить взаимоотношения поэтов первой трети XIX в. можно, построив по приведенным в табл. 4 сведениям об индексах маркемной близости авторов направленный граф (рис. 2).

Размер узлов данного графа отражает степень вовлеченности автора в предпочтительные маркемные связи в рамках исследуемого хронологического среза, направление этих связей показано стрелками, а цифры на стрелках обозначают силу связи между авторами, т. е. индекс их маркемной близости, выраженный в промилле.

Т а б ли ц а 5

Связующче маркемы русской поэзии первой трети ХIX в.

\begin{tabular}{|c|c|c|c|c|c|}
\hline Маркема & ИнСВес & Маркема & ИнСВес & Маркема & ИнСВес \\
\hline воспоминание & 0,568822 & сладость & 0,114515 & торжество & 0,044949 \\
\hline блаженство & 0,3562 & богатство & 0,107121 & взгляд & 0,0445 \\
\hline наслажждение & 0,323053 & спокойствие & 0,1031 & забвенье & 0,044499 \\
\hline вдохновение & 0,311192 & пламень & 0,091221 & разлука & 0,042698 \\
\hline благословенье & 0,301695 & преступленье & 0,084225 & презренье & 0,04183 \\
\hline счастье & 0,268319 & народ & 0,081454 & бессмертие & 0,040006 \\
\hline воображенье & 0,253288 & любовь & 0,074296 & невинность & 0,038535 \\
\hline страданье & 0,237654 & восторг & 0,073412 & свиданье & 0,037753 \\
\hline мгновение & 0,234181 & чувство & 0,073105 & время & 0,037179 \\
\hline сердце & 0,206572 & заблуждение & 0,071455 & сострадание & 0,036519 \\
\hline молодость & 0,205037 & прелесть & 0,0695 & размышленье & 0,036186 \\
\hline провиденье & 0,188151 & звезда & 0,059471 & отчаяние & 0,035237 \\
\hline человек & 0,177796 & небеса & 0,057112 & спасение & 0,02928 \\
\hline радость & 0,170862 & почзелуй & 0,056678 & величие & 0,027205 \\
\hline отечество & 0,16901 & надежда & 0,055112 & светило & 0,026259 \\
\hline уединение & 0,164129 & благодарность & 0,051155 & глаза & 0,025926 \\
\hline природа & $\mathbf{0 , 1 5 9 3 8 1}$ & исступление & 0,050219 & благость & 0,023673 \\
\hline сновидение & 0,159205 & приговор & 0,048602 & старость & 0,023657 \\
\hline очарование & 0,148613 & снисхождение & 0,048292 & ненависть & 0,022981 \\
\hline добродетель & 0,140133 & стремленье & 0,047266 & голос & 0,0226 \\
\hline разговор & 0,139599 & утешенье & 0,047148 & судьба & 0,022573 \\
\hline веселье & 0,129863 & призрак & 0,046653 & воздух & 0,017227 \\
\hline молчание & 0,12789 & вероломство & 0,046221 & смерть & 0,016031 \\
\hline солнце & 0,122822 & изветок & 0,045339 & весна & 0,012099 \\
\hline волненье & 0,122052 & жребий & 0,04528 & слава & 0,010009 \\
\hline небосклон & 0,119504 & мужество & 0,045115 & & \\
\hline
\end{tabular}




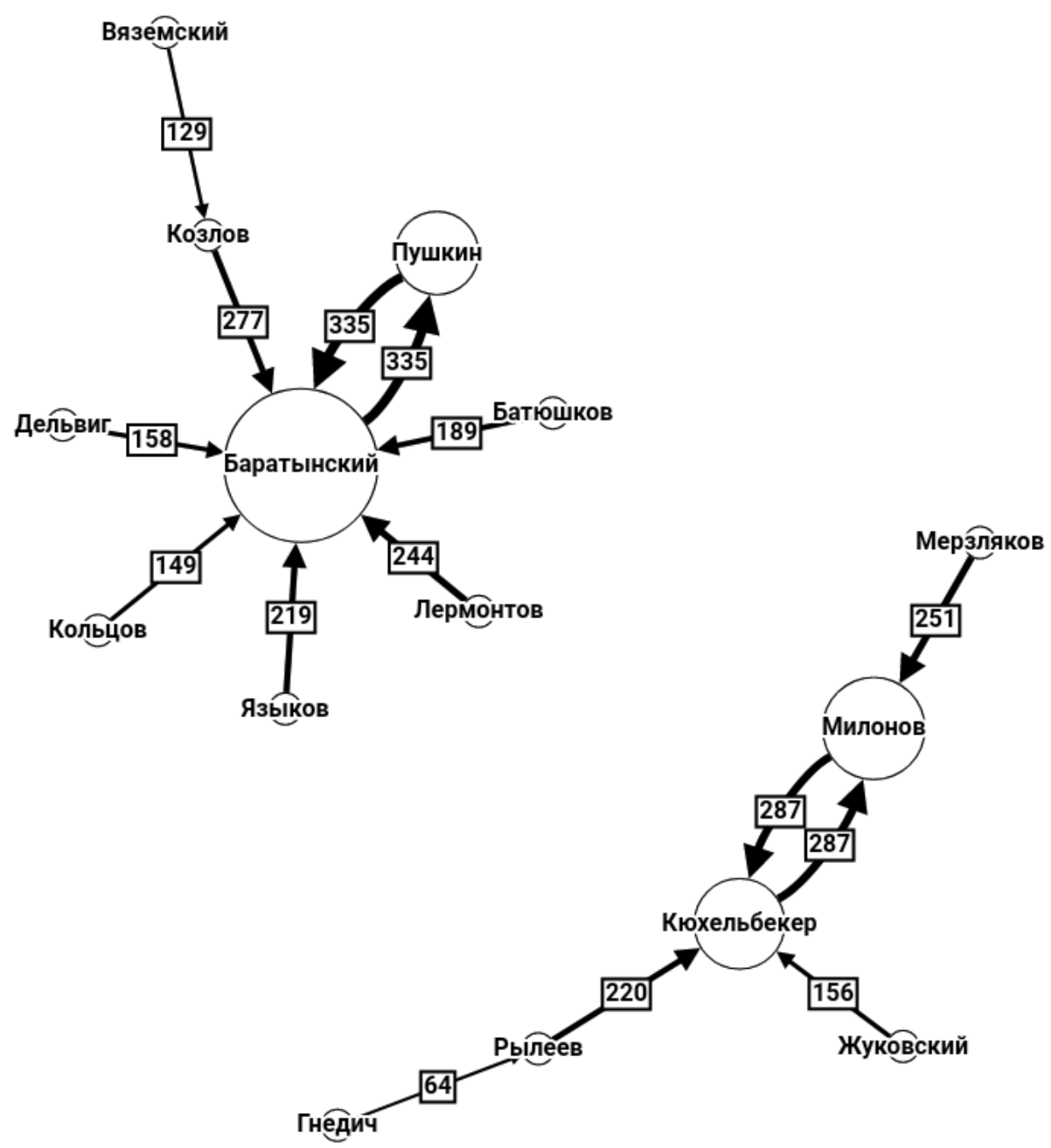

Puc. 2. Граф предпочтительных маркемных связей поэтов первой трети XIX в.

Прежде всего рассмотрим пары авторов, соединенных обоюдной связью. В первой трети XIX в. наблюдается 2 таких пары (Баратынский - Пушкин и Милонов - Кюхельбекер) и, соответственно, 2 центра аттракции (ЦА). Авторы, образующие как входящие, так и исходящие связи, являются центрами-посредниками (ЦП) различных уровней по удаленности от ЦА. В нашем случае ЦП нулевого уровня являются все авторы, составляющие центры аттракции: А. С. Пушкин (1 входящая и 1 исходящая связь, обе c Е. А. Баратынским), Е. А. Баратынский (1 исходящая связь с А. С. Пушкиным и 7 входящих), М. В. Милонов (2 входящих связи и 1 исходящая) и В. К. Кюхельбекер (1 исходящая связь и 3 входящих); очевидно, что крупнейшим ЦП нулевого уровня оказывается Е. А. Баратынский. И. И. Козлов и К. Ф. Рылеев (с 1 входящей и 1 исходящей связью) формируют ЦП первого уровня. ЦП более высоких уровней отсутствуют. Наличие в первой трети XIX в. 2 центров аттракции, а не одного, как в XVIII в., может быть связано с поступательным развитием литературы, возникновением нового направления - романтизма, существовавшего на фоне популярного в конце XVIII - начале XIX в. сентиментализма.

ЦП А. С. Пушкина крайне невелик и включает, в сущности, лишь его взаимонаправленную связь с Е. А. Баратынским. В образовании этой связи участвуют 23 маркемы, среди которых 9 составляют ядро, a 14 - периферию. При помощи дальнейшей стратификации можно установить состав ядра (воспоминание, вдохновение, воображение, наслаждение) и периферии (блаженство, очарованье, уединение, мгновение, небосклон) в ядерной маркемной лексике данного ЦП. Аналогично определяются и ядро (cmpaданье, сновидение, размылиленье, разговор, молчание, забвение, волнение) и периферия (счастье, человек, веселье, молодость, свидание, природа, поцелуй) в периферийном классе маркем пушкинского ЦП.

ЦП Е. А. Баратынского, напротив, является наиболее крупным ЦП рассматриваемого хронологического среза. Помимо упоминавшейся ранее обоюдной связи, он включает и 6 входящих связей - с И. И. Коз- 
ловым, А. А. Дельвигом, К. Н. Батюшковым, А. В. Кольцовым, Н. М. Языковым, М. Ю. Лермонтовым. В формировании этих связей задействованы 17 маркем, но проходящими из них являются лишь 3 (поиелуй, забвение, свидание). Интересно, что большая часть этих маркем (10 маркем) составляет ядро. В пределах ядра, соответственно, выделяется ядерная (заблуждение, поцелуй, любовь, чувство, благодарность) и периферийная (звезда, ияветок, взгляд, забвенье, небеса, пламень) маркемная лексика. Допускает такое разбиение и незначительная группа периферийных маркем (свиданье, время, глаза и голос, судьба, воздух, весна соответственно). Особенности маркемной лексики каждого из изученных нами центров-посредников можно выявить, вычитая ИнСвВес маркем ЦП- $0_{\text {Пуш }}$ из ИнСВеса маркем центра-посредника, образовавшегося вокруг Е. А. Баратынского. Результаты этого действия отражены в табл. 6 и на рис. 3. Положительная разность говорит о специфичности маркемы для центра Е. А. Баратынского, отрицательная - о ее характерности для центра А. С. Пушкина. Полученные таким образом классы маркем оказываются почти равными друг другу по обьему. Однако поскольку Е. А. Баратынский, в отличие от А. С. Пушкина, имеет множество входящих связей, именно он является ведущим автором в ЦА Пуш-Бар Разумеется, «ведущий» не значит «наиболее важный для литературного процесса» или «самый известный,
Т а б ли ц а 6

Список условно-специфичных маркем ЦП-оПуш и ЦП-ОБар

\begin{tabular}{|c|c|c|c|}
\hline Маркема & $\begin{array}{c}\text { Разность } \\
\text { ИнСВесов }\end{array}$ & Маркема & $\begin{array}{c}\text { Разность } \\
\text { ИнСВесов }\end{array}$ \\
\hline воспоминанье & $-0,11643$ & природа & $-0,02392$ \\
\hline вдохновение & $-0,10952$ & забвенье & 0,008025 \\
\hline воображенье & $-0,09763$ & весна & 0,012099 \\
\hline наслаждение & $-0,07795$ & свиданье & 0,013018 \\
\hline блаженство & $-0,05619$ & воздух & 0,017227 \\
\hline очарованье & $-0,05589$ & судьба & 0,022573 \\
\hline уединенье & $-0,05513$ & голос & 0,0226 \\
\hline мгновенье & $-0,05385$ & глаза & 0,025926 \\
\hline небосклон & $-0,05075$ & поцелуй & 0,036927 \\
\hline страданье & $-0,05008$ & время & 0,037179 \\
\hline сновиденье & $-0,04786$ & пламень & 0,043212 \\
\hline размышленье & $-0,04644$ & небеса & 0,043428 \\
\hline разговор & $-0,0433$ & взгляд & 0,0445 \\
\hline молчанье & $-0,04051$ & цветок & 0,045339 \\
\hline волненье & $-0,03613$ & звезда & 0,048329 \\
\hline & $-0,03117$ & благодар- & 0,051155 \\
\hline счастье & $-0,03103$ & чувство & 0,053657 \\
\hline человек & $-0,02965$ & любовь & 0,053832 \\
\hline веселье & $-0,02881$ & заблуждение & 0,071455 \\
\hline младость & & \\
\hline
\end{tabular}

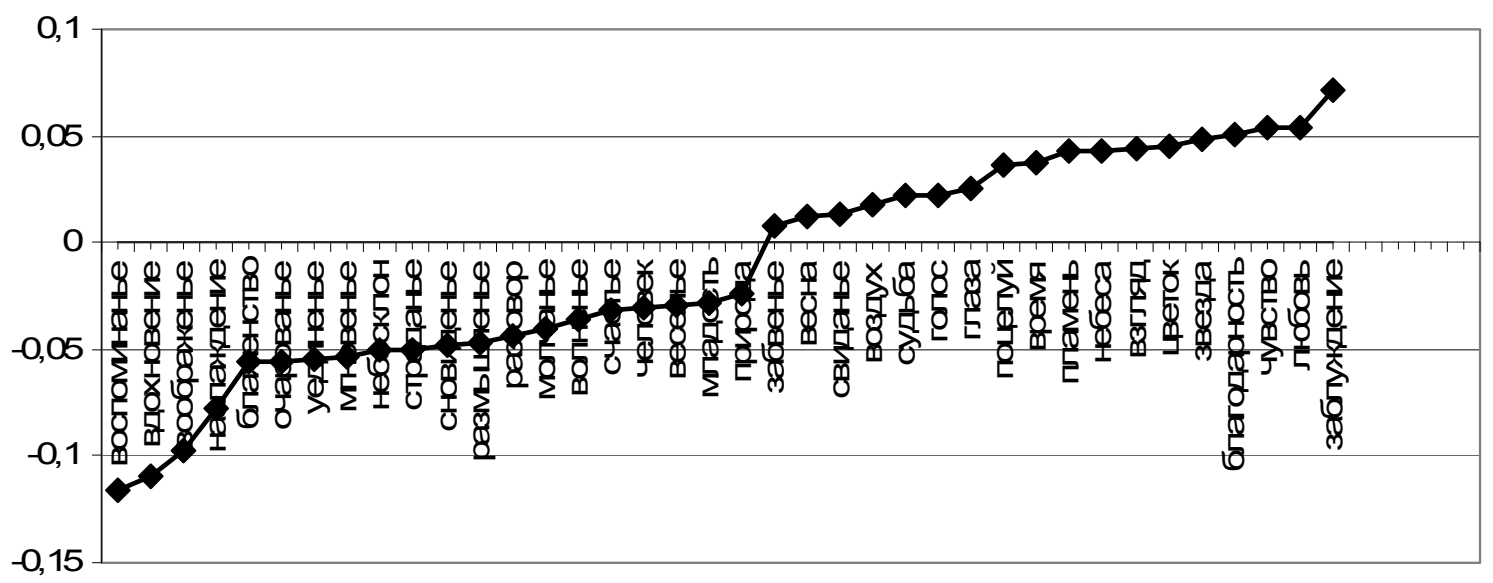

Puc. 3. Условно-специфичные маркемы ЦП Бар $и$ ЦП Пуш

популярный», а скорее «наиболее типичный, характерный, обычный для рассматриваемого хронологического среза (с точки зрения маркемной лексики)». Интересно, что среди условно-специфичных маркем ЦП Е. А. Баратынского много натурфактов (весна, воздух, пламень, небеса, иветок, звезда).

Второй центр аттракции русской поэзии первой трети XIX в. существенно меньше и включает 6 авторов. Он складывается вокруг соединенной взаимо- направленной связью пары Кюхельбекер-Милонов. Остановимся на образованных этими авторами ЦП нулевого уровня.

ЦП М. В. Милонова, кроме связи с В. К. Кюхельбекером, включает и входящую связь с А. Ф. Мерзляковым. В этих связях используются 34 маркемы, из них 15 являются проходящими (благословение, блаженство, преступление, добродетель, страдание, отечество, богатство, утешение, счастье, человек, 
природа, надежда, призрак, сердие, радость). 11 маркем входят в состав ядра, а 23 относятся к периферийной лексике. Ядерная лексика разбивается, в свою очередь, на ядро (благословение, блаженство, спокойствие, воспоминание) и периферию (преступление, надежда, добродетель, страдание, отечество, провидение, богатство). Для периферийных маркем объем ядра и периферии примерно одинаков (11 и 12 маркем соответственно).

В ЦП В. К. Кюхельбекера, наряду с его связью с М. В. Милоновым, вовлечены также входящие связи с В. А. Жуковским и К. Ф. Рылеевым (являющимся ЦП первого уровня). Проходящими здесь являются 18 маркем: блаженство, богатство, веселье, воспоминание, восторг, добродетель, надежда, наслаждение, отечество, приговор, призрак, природа, провидение, радость, сердие, страдание, счастье, человек. Всего в предпочтительных связях участвует 37 маркем, около двух третей которых составляет периферийная лексика - 25 маркем, из которых большинство (15) входит в ядро, и лишь 10 в периферию. Для ядерной маркемной лексики, напротив, объем ядра меньше и составляет 5 маркем (воспоминание, блаженство, благословение, добродетель, провидение), тогда как периферийных маркем 7 (отечество, наслаждение, страдание, мгновение, богатство, вдохновение, счастье).

Для этих двух центров-посредников можно, как и в случае с А. С. Пушкиным и Е. А. Баратынским, определить специфичные маркемы образующих их авторов. Данные об этих условно-специфичных мар- кемах представлены в табл. 7 и на рис. 4 (здесь вычисляется разность ИнСВесов маркем ЦП Кюх и ЦП Интересно, что для 4 маркем (отчаяние, светило, торжество, уединение) эта разность равна 0 , и следовательно, они не являются условно-специфичными ни для ЦП В. К. Кюхельбекера, ни для ЦП М. В. Милонова. Так как количество специфичных маркем больше для центра В. К. Кюхельбекера, и учитывая его 2 входящие связи, одна из которых - с центром-посредником 1 уровня (Рылеев), именно В. К. Кюхельбекер является ведущим автором в паре МилоновКюхельбекер.

Остановимся теперь на центрах-посредниках первого уровня. Один из них (И. И. Козлов) входит в состав графа, образовавшегося вокруг центра аттракции Пушкин-Баратынский. Он имеет 1 входящую связь (с П. А. Вяземским) и 1 исходящую (с Е. А. Баратынским). В образовании этих связей участвуют всего 10 маркем (чувство, прелесть, небеса, пламень, звезда, восторг, цветок, любовь, голос, взгляд), из которых половина (чувство, небеса, пламень, звезда, любовь) являются проходящими, 2 (прелесть, восторг) входящими и 3 (цветок, голос, взгляд) исходящими.

Второй ЦП первого уровня (К. Ф. Рылеев) связан с графом, сформированным вокруг центра аттракции Милонов-Кюхельбекер. Он также отличается 1 входящей связью (Н. И. Гнедич) и 1 исходящей (В. К. Кюхельбекер). В этих связях задействованы 33 маркемы, из которых 9 (богатство, молчание, отечество, пламень, приговор, природа, радость,

Т а б ли ц а 7

Список условно-специфичных маркем ЦП-ОМил и ЦП-ОКюх

\begin{tabular}{|c|c|c|c|c|c|}
\hline Маркема & $\begin{array}{c}\text { Разность } \\
\text { ИнСВесов }\end{array}$ & Маркема & $\begin{array}{c}\text { Разность } \\
\text { ИнСВесов }\end{array}$ & Маркема & $\begin{array}{c}\text { Разность } \\
\text { ИнСВесов }\end{array}$ \\
\hline спокойствие & $-0,103099721$ & торжество & 0 & спасенье & 0,029279684 \\
\hline благословение & $-0,056578704$ & уединенье & 0 & добродетель & 0,031408736 \\
\hline стремленье & $-0,047265754$ & надежда & 0,003623907 & отечество & 0,033219888 \\
\hline невинность & $-0,038535244$ & сердце & 0,003891487 & бессмертие & 0,040006353 \\
\hline преступленье & $-0,036727431$ & человек & 0,004313498 & презренье & 0,041830206 \\
\hline разлученье & $-0,032446709$ & приговор & 0,009922458 & разговор & 0,042096589 \\
\hline прелесть & $-0,029543871$ & восторг & 0,011762854 & молчанье & 0,042355351 \\
\hline величие & $-0,027205278$ & веселье & 0,013947694 & провиденье & 0,045919685 \\
\hline сладость & $-0,024381973$ & счастье & 0,014759194 & вероломство & 0,046221281 \\
\hline благость & $-0,023673266$ & богатство & 0,017243658 & исступленье & 0,05021906 \\
\hline утешенье & $-0,017473648$ & пламень & 0,021691727 & состраданье & 0,056129115 \\
\hline призрак & $-0,003212639$ & ненависть & 0,022980915 & воспоминанье & 0,067695573 \\
\hline радость & $-0,000875945$ & блаженство & 0,027163917 & вдохновенье & 0,068832733 \\
\hline природа & $-0,000572338$ & страданье & 0,027268161 & мгновенье & 0,094117891 \\
\hline отчаянье & 0 & наслажденье & 0,028094013 & & \\
\hline светило & 0 & & & & \\
\hline
\end{tabular}




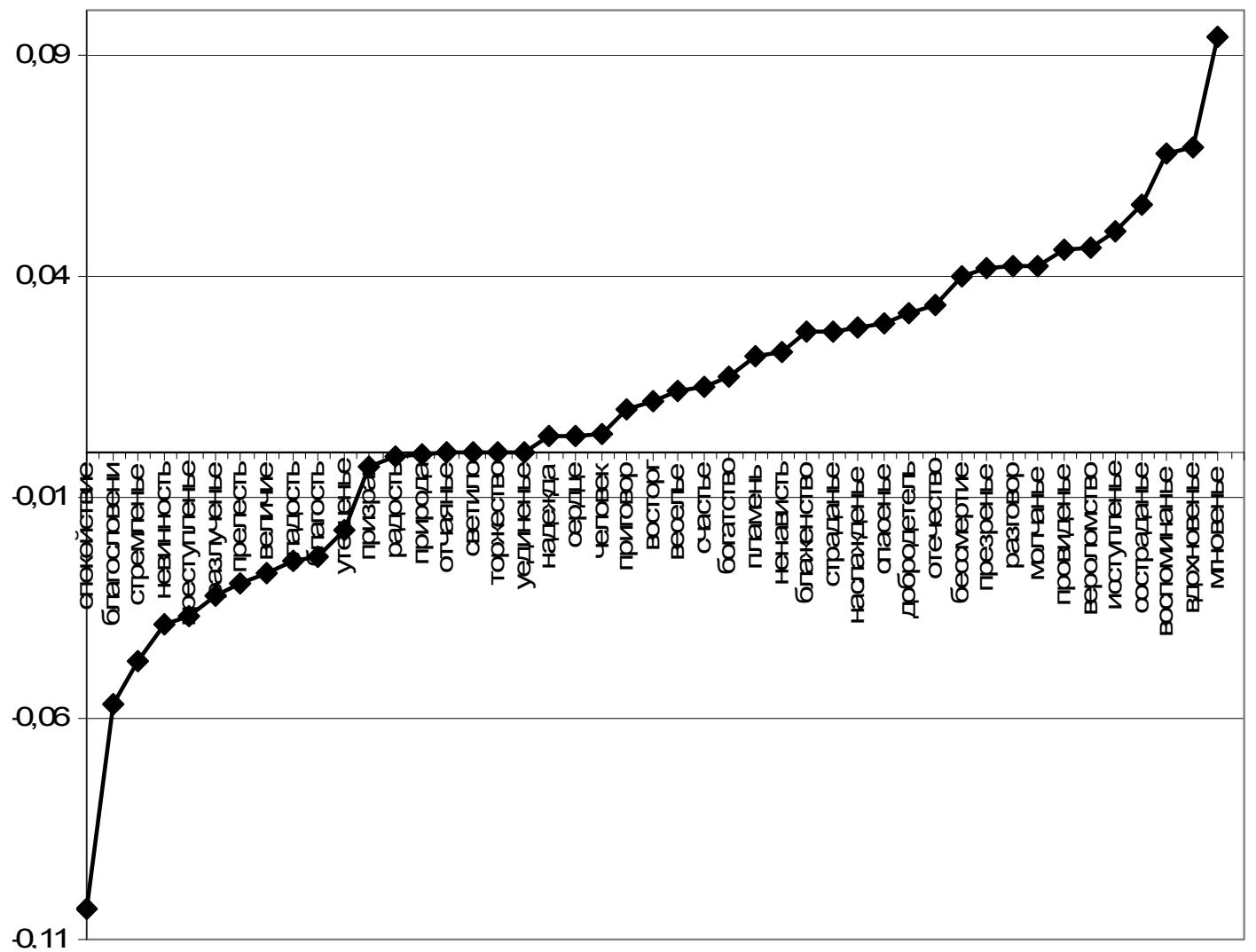

Puc. 4. Условно-специфичные маркемы ЦП- $0_{\text {Пуш }}$ и ЦП- $0_{\text {Бар }}$

сердие, человек) являются проходящими, 7 (жребий, любовь, молодость, мужество, народ, солние, старость) входящими; преобладают исходящие маркемы (17).

\section{Заключение}

Итоги углубленного исследования маркемного состава языка русской поэзии первой трети XIX в. таковы.

Для сводного маркемного списка определены ядерная и периферийная лексика, его доминанта воспоминание и вице-доминанта блаженство.

На основе вновь полученных данных проведена оценка маркемной лексики сводного списка с точки зрения ее семантики (рост значимости эмоциональных и ментально-перцептивных маркем).

Установлены наиболее характерные по маркемной лексике представители русской поэзии начала XIX в. - нуклеары Е. А. Баратынский, А. А. Дельвиг и И. И. Козлов, а также наиболее специфичные - маргиналы (В. И. Жуковский, П. А. Вяземский, Н. И. Гнедич), среди которых выделен супермаргинал (Н. И. Гнедич).

По данным об индексах маркемной близости авторов построен граф, наглядно отражающий их взаимодействие. С его помощью охарактеризованы
2 центра аттракции - пары Пушкин-Баратынский и Кюхельбекер-Милонов, а также центры-посредники нулевого и первого уровней.

Наиболее важным для исследуемого временного промежутка с точки зрения его маркемной лексики является Е. А. Баратынский, так как он формирует один из двух центров аттракции среза, имеет 7 входящих связей и является нуклеаром.

Настоящая работа представляет собой лишь один из этапов расширения и обновления результатов исследования русской поэзии средствами маркемного анализа, поэтому ее закономерной перспективой является охват дальнейших периодов ее развития, вплоть до начала XXI в. Расширение временных рамок даст возможность изучить и межсрезовые связи авторов на базе индекса их маркемной близости. Любопытно также сравнить и полученные графы предпочтительных маркемных связей представителей различных хронолгических срезов.

\section{ЛИТЕРАТУРА}

1. Кашкина А. В. Маркемный анализ языка русской поэзии : дис. ... канд. филол. наук. Воронеж, 2013. 544 с.

2. Кретов A. А. Понятие маркемы : методика выявления и практика использования // Универсалии русской литературы - 2 : сб. ст. / под ред. А. А. Фаустова ; Воро- 
нежский государственный университет. Воронеж : Наука-Юнипресс, 2010. С. 138-153.

3. Артемова О. Г. Языковые ключи к английской литературе от Шекспира до Фаулза : монография / под ред. проф. А. А. Кретова. Воронеж : НАУКА-ЮНИПРЕСС, 2020. (Серия: Библиотека маркемологии. Т. 4). $596 \mathrm{c}$.

4. Кретов А. А., Катов М. В. Сквозь призму маркем : Н. В. Гоголь в ближайшем контексте русской литературы // Вестник Воронеж. гос. ун-та. Сер.: Лингвистика и межкультурная коммуникация. 2009. № 2. С. 12-21.

5. Фаустов А. А. Маркемный портрет А. П. Чехова // Вестник Воронеж. гос. ун-та. Сер.: Лингвистика и межкультурная коммуникация. 2010. № 2. С. 12-16.

\section{REFERENCES}

1. Kashkina A. V. Markemnyj analiz jazyka russkoj poezii [Markeme analysis of Russian poetic language]. $\mathrm{PhD}$ Dissertation. Voronezh: Voronezh State University, 2013. 544 p.

Кашкина А. В., кандидат филологических наук E-mail: shtil72@yandex.ru

Поступила в редакциию 2 сентября 2021 г.

Принята к публикации 15 октября 20212.

\section{Для цитирования:}

Кашкина А. В. Визуализация маркемных связей русских поэтов первой трети XIX века // Вестник Воронежского государственного университета. Серия: Лингвистика и межкультурная коммуникация. 2021. № 4. C. 146-156. DOI: https://doi.org/10.17308/lic.2021.4/3822
2. Kretov A. A. Ponjatije markemy : metodica vyjavlenija i praktika ispol'zovanija [The concept of markeme: the algorithm of identification and practice of using]. In: Universalii russkoj literatury. Voronezhskij gos. un-t. 2010. Pp. 138-153.

3. Artemova O. G. Yazykovyje kluchi k anglijskoj literature ot Shekspira do Faulza [Language keys to English literature from Shakespeare to Fowls]. Voronezh: NAUKA-YUNIPRESS, 2020. 596 p.

4. Kretov A. A., Katov H. V. Skvoz' prizmu markem: N. V. Gogol' v blizhajshem kontekste russkoj literatury [Through the prizm of markemes: N. V. Gogol in the nearest context of Russian literature]. In: Vestn. Voronezhskogo gos. un-ta. Lingvistika i mezhkul'turnaja kommunikacija. 2009. No. 2. Pp. 12-21.

5. Faustov A. A. Markemnyj portret A. P. Chekhova [Markeme portrait of A. P. Chekhov]. In: Vestn. Voronezhskogo gos. un-ta. Lingvistika i mezhkul'turnaja kommunikacija. 2010. No. 2. Pp. 12-16.

\section{Kashkina A. V., Candidate of Philology \\ E-mail: shtil72@yandex.ru}

Received: 2 September 2021

Accepted: 15 October 2021

\section{For citation:}

Kashkina A. $V$. Visualization of markeme links between Russian poets of the first third of the XIXth century. Proceedings of Voronezh State University. Series: Linguistics and Intercultural Communication. 2021. No. 4. Pp. 146-156. DOI: https://doi.org/10.17308/lic.2021.4/3822 